\title{
Endermologie versus Low Level Laser Therapy on Post Mastectomy Lymphedema
}

\author{
MONA M.A. ZIETHAR, M.Sc.*; INTSAR S. WAKED, Ph.D.*; ROKAIA A. TOSON, Ph.D.* and \\ RAGAB A.A. SHERIF, M.D.** \\ The Department of Physical Therapy for Surgery, Faculty of Physical Therapy, Cairo University* and \\ The Department of Surgical Oncology, Damanhour Oncology Centre***
}

\begin{abstract}
Background: Breast cancer-related lymphedema (BCRL) is a major side effect and a complication of breast cancer surgery and radiotherapy, causing chronic lymphedema in the arm.

Aim of Study: This study was conducted to compare between efficacy of Endermologie and Low Level Laser Therapy (LLLT) in treatment of post mastectomy lymphedema.

Subjects and Methods: Thirty women diagnosed clinically by oncologist/physician as unilateral breast cancer with secondary upper limb lymphedema post mastectomy, they were selected from Damanhour Oncology Centre suffering from grade II lymphedema without skin changes one year post mastectomy based on tape and volumetric assessment. Their age ranged from 40 to 60 years. They were assigned randomly into two groups (A) and (B) equal in number. Group (A) received 30min Endermologie 3 times per week in addition to routine physical therapy program (manual lymphatic drainage, compression bandage, active range of motion and elevation), hygiene and skin carefor 6 weeks. While, Group (B) received 20min LLLT 3 times per week in addition to routine physical therapy program (manual lymphatic drainage, compression bandage, active range of motion and elevation), hygiene and skin care for 6 weeks. Upper limb lymphedema was evaluated by tape and volumetric assessment before and after the intervention.
\end{abstract}

Results: There was no significant difference in upper limb volume and circumference between both groups pre-treatment $(p>0.05)$. Comparison between the group (A) and (B) posttreatment revealed a significant decrease in upper limb volume and circumference of the group (A) compared with that of the group (B) $(p>0.05)$.

Conclusion: These results suggested that Endermologie was more effective than LLLT in reducing limb circumference and volume in post mastectomy lymphedema.

Key Words: Mastectomy-Lymphedema-Endermologie Low level laser therapy.

Correspondence to: Dr. Mona M.A. Ziethar, The Department of Physical Therapy for Surgery, Faculty of Physical Therapy, Cairo University

\section{Introduction}

A MASTECTOMY is the removal of all the tissues from one or both breasts. Mastectomies are primarily performed to remove or prevent breast cancer. The operation is most often carried out to remove existing cancerous cells within the breast and thereby reduce the potential for breast cancer to spread [1].

Breast cancer is the most common malignantdisease in women. Lymphedema is a significant health problem for cancer survivors. It affects $21.4 \%$, indicating 1 in every 5 patients following breast cancer treatment. BCRL results from disruption to the lymphatic system that prevents adequate drainage from lymphatic vessels causing proteinrich lymph fluid to accumulate in the interstitial space [2].

Breast cancer-related lymphedema is the most common chronic impairment following breast cancer surgery. Lymphedema is a chronic disease where lymph accumulation in the limbs was mostly due to obstruction of the proximal lymphatic system due to lymph node dissection for cancer treatment. It is a debilitating disease which can lead to swollen, heavy, painful and infection prone limbs [3].

Breast cancer-related lymphedema (BCRL) is a major side effect of surgical treatment and radiotherapy, causing chronic lymphedema in the arm. Normal lymphatic drainage plays a key role toeliminate and transfer waste matter from the body (bilirubin, pigments) and ultimately prevents swelling. Individuals with BCRL have a malfunctioning lymphatic system which delays lymphatic drainage, causing an abnormal increase of tissue protein and resulting in chronic inflammation, fibrosis, pain, 
limited range of motion or paraesthesia. This leads to functional disabilities and mental problems such as anxiety and depression. Areas with BCRL are reported to have decreased local immune function, result in having a higher risk of infection and inflammation [4]

Endermologie treatment used to facilitate the lymphatic drainage from the affected limb by using mechanized treatment head that allow continuous folding and unfolding of the skin under the continuous action of the rollers allowing for smooth and regulated deep tissue mobilization. As the viscosity of the subcutaneous fat layer reduces, blood flow and lymphatic drainage increase, facilitating the elimination of excess fluid and metabolites and improving overall cellular function [5].

Low Level Laser Therapy increases the pumping speed and regeneration (lymphangiogenesis) of lymphatic vessels and the lymphatic flow. It also provides lymphatic collateralization by increasing the diameter and contraction the lymphatic vessels in the damaged or untreated tissues. It stimulates the phagocytic activity of the neutrophils $\&$ monocytosis and activates the immune system [6].

So the purpose of this study was conducted to compare between efficacy of Endermologie and LLLT in treatment of post mastectomy lymphedema.

\section{Subjects and Methods}

Subjects:

Thirty women were suffering from grade II lymphedema one-year post mastectomy based on tape and volumetric assessment. They were assigned randomly into two groups (A) and (B) equal in number. Group (A) received 30min Endermologie 3 times per week in addition to routine physical therapy program (manual lymphatic drainage, compression bandage, active range of motion and elevation), hygiene and skin care for 6 weeks. While, Group (B) received 20min LLLT 3 times per week in addition to routine physical therapy program (manual lymphatic drainage, compression bandage, active range of motion and elevation), hygiene and skin care for 6 weeks.

The inclusion criteria were as follow: Only females participated in the study, patients' age was ranged between 40-60 years, all patients sufferedfrom grade II lymphedema without skin changes one year post mastectomy, all patients had girth
$>2 \mathrm{~cm}$ circumferential difference and/or volume $>200 \mathrm{~mL}$ compared with the uninvolved upper extremity, all patients were right-dominant hand and all patients enrolled to the study had their informed consent.

The exclusion criteria were as follow: Patients who had primary lymphedema, diabetes mellitus, pregnancy, recurrent cancer, current or recent cellulitis, current metastases, venous thrombosis, photo sensitivity, phlebitis in development stage, infection or receiving anti-coagulant treatment. All women participated in this study signed an informed consent form before data collection. After ethical approval, thirty women were selected from Damanhour Oncology Centre, Beheira, Egypt. The study was conducted from Augest 2020 to Novemer 2020 .

\section{Materials:}

- Tape measurement was used to measure upper limb circumference for both sides at 5 locations.

- Volumetric measurement was used to measure upper limb volume at both sides.

- Endermologie machine.

- Low level laser therapy.

\section{Procedures:}

Group (A): Endermologie group:

Every patient ingroup (A) was completely informed by the protocol of treatment and was informed by the benefits of the Endermologie machine to gain their cooperation and motivation during treatment.

Instructions were given to patient to lie in supine lying position with empty bladder, affected upper limb was exposed and the skin was cleaned with alcohol.

Application of manual lymphatic drainage to head, neck, abdominal, axillary lymph nodes, axillo-axillary anastmosis and affected upper limb lymph nodes.

The therapist applied the heart-beat sensor on her thumb and the machine started reading heart rate, the therapist then started to set the treatment time for 30 minutes then pressed the start putton.

The therapist started the treatment by applying the head of the machine on posterior thorax, breast, shoulder, upper arm, forearm and hand, moved it in anti-clockwise direction. 
The session will last 30min and preceded the application of bandages as suggested during preliminary studies [7].

\section{Group (B): Low level laser therapy:}

Every patient ingroup (B) was completely informed by the protocol of treatment and was informed by the benefits of the LLLT to gain their cooperation and motivation during treatment.

Instructions were given to patient to lie in supine lying position with empty bladder, affected upper limb was exposed and the skin was cleaned with alcohol.

Application of manual lymphatic drainage to head, neck, abdominal, axillary lymph nodes, axillo-axillary anastmosis and affected upper limb lymph nodes.

Laser therapy was administrated as points on antecubital fossa (3 points) and at points on the axilla (7 points) where the lymph nodes accumulated. The wavelength was $904 \mathrm{~nm}$, average output was $5 \mathrm{~mW}$, maximum frequency was $2800 \mathrm{~Hz}$, pulse duration was 50n.m, average dose was $1,5 \mathrm{~J} / \mathrm{cm}^{2}$, each point had $2 \mathrm{~min}$,total treatment duration was $20 \mathrm{~min}$, frequency was 3 sessions/week for 6 weeks [8].

\section{Statistical analysis:}

Normal distribution of data was checked using the Shapiro-Wilk test for all variables. Descriptive statistics and $t$-test were conducted for comparison of the mean age between groups. Chi-squared test was conducted for comparison of distribution of affected limb between groups. Paired $t$-test for comparison between pre and post treatment mean values of upper limb volume and circumference within group. Unpaired $t$-test was conducted for comparison between groups. The level of signifi- cance for all statistical tests was set at $(p<0.05)$. All statistical measures were performed through the statistical package for social studies (SPSS) version 22 for windows.

\section{Results}

\section{Subject characteristics:}

Table (1) showed the mean \pm SD of subjects age of group (A) and (B). There was no significant difference between both groups in the mean age $(p<0.05)$. Also, there was no significant difference in the distribution of all females and affected sides between both groups $(p<0.05)$.

\section{Effect of treatment on upper limb volume and circumference:}

The results of this study revealed that there was a significant decrease in upper limb volume and circumference post-treatment in the group (A) and (B) compared with that pre-treatment $(p>0.05)$. The percent of decrease in upper limb volume in the group (A) was $18.45 \%$ and that in group (B) was $8.43 \%$. The precents of decrease in circumference of wrist, midway between wrist \& olecranon, olecranon, midway between olecranon \& axilla and axilla of the group (A) were $11.65 \%, 13 \%$, $13.82 \%, 11.14 \%$ and $12.43 \%$ respectively; The precents of decrease in circumference of wrist, midway between wrist \& olecranon, olecranon, midway between olecranon \& axilla and axilla of the group (B) were $5.81 \%, 8.51 \%, 3.8 \%, 6.34 \%$ and $9.6 \%$ respectively. Also, there was no significant difference in upper limb volume and circumference between both groups pre-treatment $(p>0.05)$. Comparison between the group (A) and (B) post-treatment revealed a significant decrease in upper limb volume and circumference at wrist, midway between wrist \& olecranon, olecranon, midway between olecranon \& axilla and axilla of the group (A) compared with that of the group (B) $(p>0.05)$. (Table 2, Figs. 1,2).

Table (1): Comparison of subject characteristics between the group (A) and (B).

\begin{tabular}{cccc}
\hline & $\begin{array}{c}\text { Group (A) } \\
\mathrm{X} \pm \mathrm{SD}\end{array}$ & $\begin{array}{c}\text { Group (B) } \\
\mathrm{X} \pm \mathrm{SD}\end{array}$ & $\begin{array}{c}p \text { - } \\
\text { value }\end{array}$ \\
\hline Age (years) & $46.2 \pm 3.25$ & $45.46 \pm 4.4$ & 0.6 \\
$\begin{array}{c}\text { Affected side: } \\
\text { Right side }\end{array}$ & $7(47 \%)$ & $9(60 \%)$ & 0.46 \\
Left side & $8(53 \%)$ & $6(40 \%)$ & \\
\hline
\end{tabular}

X: Mean. SD: Standard deviation. $\quad p$-value: Probability value. 
Table (2): Mean upper limb volume and circumference pre and post-treatment of group (A) and (B).

\begin{tabular}{|c|c|c|c|c|c|c|}
\hline & Pre-treatment & Post- treatment & \multirow{2}{*}{ MD } & \multirow{2}{*}{$\begin{array}{l}\text { Percentage } \\
\text { of change }\end{array}$} & \multirow{2}{*}{$\begin{array}{c}t- \\
\text { value }\end{array}$} & \multirow{2}{*}{$\begin{array}{c}p^{-} \\
\text {value }\end{array}$} \\
\hline & $\mathrm{X} \pm \mathrm{SD}$ & $\mathrm{X} \pm \mathrm{SD}$ & & & & \\
\hline \multicolumn{7}{|c|}{ Upper limb volume $(\mathrm{ml})$ : } \\
\hline Group (A) & $245.66 \pm 25.34$ & $200.33 \pm 15.17$ & 45.33 & 18.45 & 11.06 & 0.001 \\
\hline Group (B) & $253 \pm 19.25$ & $231.66 \pm 21.84$ & 21.34 & 8.43 & 11.49 & 0.001 \\
\hline MD & -7.34 & -31.33 & & & & \\
\hline \multirow[t]{2}{*}{$t$-value } & -0.89 & -4.56 & & & & \\
\hline & $p=0.38$ & $p=0.001$ & & & & \\
\hline \multicolumn{7}{|c|}{ Limb circumference $(\mathrm{cm})$ wrist: } \\
\hline Group $(\mathrm{A})$ & $18.03 \pm 1.64$ & $15.93 \pm 2.06$ & 2.1 & 11.65 & 7.35 & 0.001 \\
\hline Group (B) & $18.43 \pm 1.06$ & $17.36 \pm 1.2$ & 1.07 & 5.81 & 2.61 & 0.02 \\
\hline MD & -0.4 & -1.43 & & & & \\
\hline \multirow{2}{*}{$t$-value } & -0.79 & -2.32 & & & & \\
\hline & $p=0.43$ & $p=0.02$ & & & & \\
\hline \multicolumn{7}{|c|}{ Midway between wrist \& olecranon: } \\
\hline Group (A) & $24.86 \pm 2.55$ & $21.63 \pm 2.85$ & 3.23 & 13 & 8.71 & 0.001 \\
\hline Group (B) & $25.86 \pm 1.58$ & $23.66 \pm 1.54$ & 2.2 & 8.51 & 10.13 & 0.001 \\
\hline $\mathrm{MD}$ & -1 & -2.03 & & & & \\
\hline \multirow{2}{*}{$t$-value } & -1.28 & -2.43 & & & & \\
\hline & $p=0.2$ & $p=0.02$ & & & & \\
\hline \multicolumn{7}{|l|}{ Olecranon: } \\
\hline Group (A) & $29.82 \pm 2.35$ & $25.7 \pm 3.19$ & 4.12 & 13.82 & 6.36 & 0.001 \\
\hline Group (B) & $30.83 \pm 2.43$ & $29.66 \pm 2.2$ & 1.17 & 3.8 & 8.12 & 0.001 \\
\hline MD & -1.01 & -3.96 & & & & \\
\hline \multirow[t]{2}{*}{$t$-value } & -1.15 & -3.95 & & & & \\
\hline & $p=0.25$ & $p=0.001$ & & & & \\
\hline \multicolumn{7}{|c|}{ Midway between olecranon \& axilla: } \\
\hline Group (A) & $36.53 \pm 4.33$ & $32.46 \pm 4.22$ & 4.07 & 11.14 & 8.64 & 0.001 \\
\hline Group (B) & $37.86 \pm 2.28$ & $35.46 \pm 2.32$ & 2.4 & 6.34 & 19.75 & 0.001 \\
\hline MD & -1.33 & -3 & & & & \\
\hline \multirow[t]{2}{*}{$t$-value } & -1.05 & -2.41 & & & & \\
\hline & $p=0.3$ & $p=0.02$ & & & & \\
\hline \multicolumn{7}{|l|}{ Axilla: } \\
\hline Group (A) & $51.5 \pm 7.01$ & $45.1 \pm 5.2$ & 6.4 & 12.43 & 9.56 & 0.001 \\
\hline Group (B) & $52.96 \pm 6.09$ & $49.8 \pm 6.22$ & 3.16 & 5.97 & 9.6 & 0.001 \\
\hline $\mathrm{MD}$ & -1.46 & -4.7 & & & & \\
\hline \multirow[t]{2}{*}{$t$-value } & -0.61 & -2.24 & & & & \\
\hline & $p=0.54$ & $p=0.03$ & & & & \\
\hline
\end{tabular}

X: Mean. $\quad$ SD: Standard deviation. $\quad p$-value: Probability value.

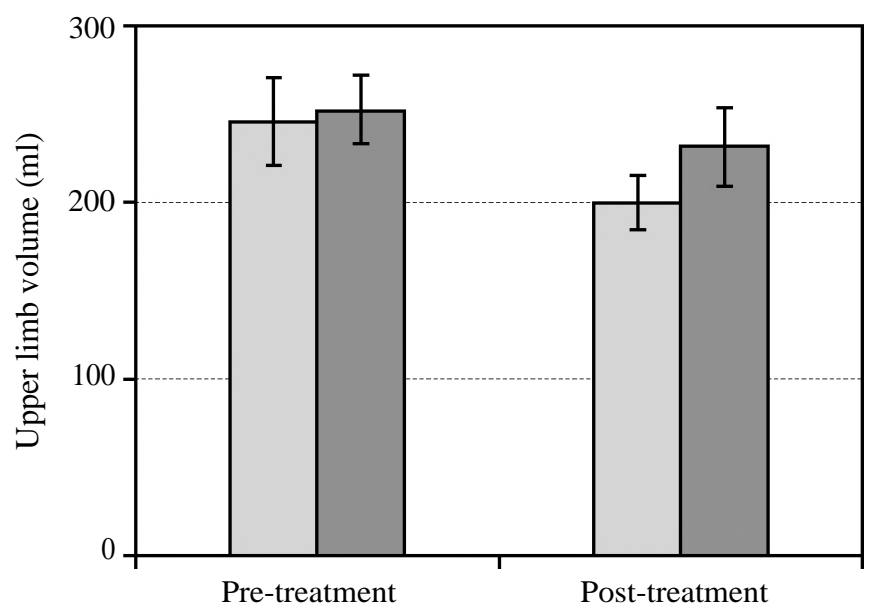

Group A $\square$ Group B

Fig. (1): Mean upper limb volume pre and posttreatment of group (A) and (B). 


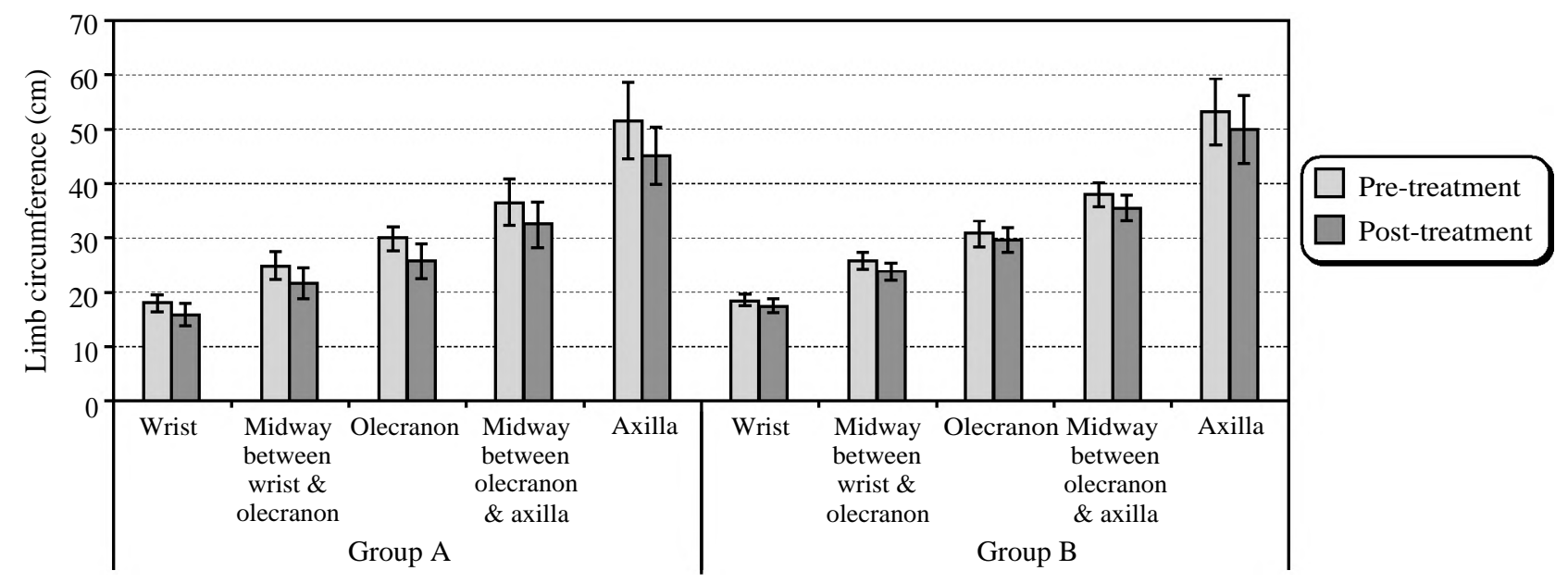

Fig. (2): Mean upper limb circumference pre and post-treatment of group (A) and (B).
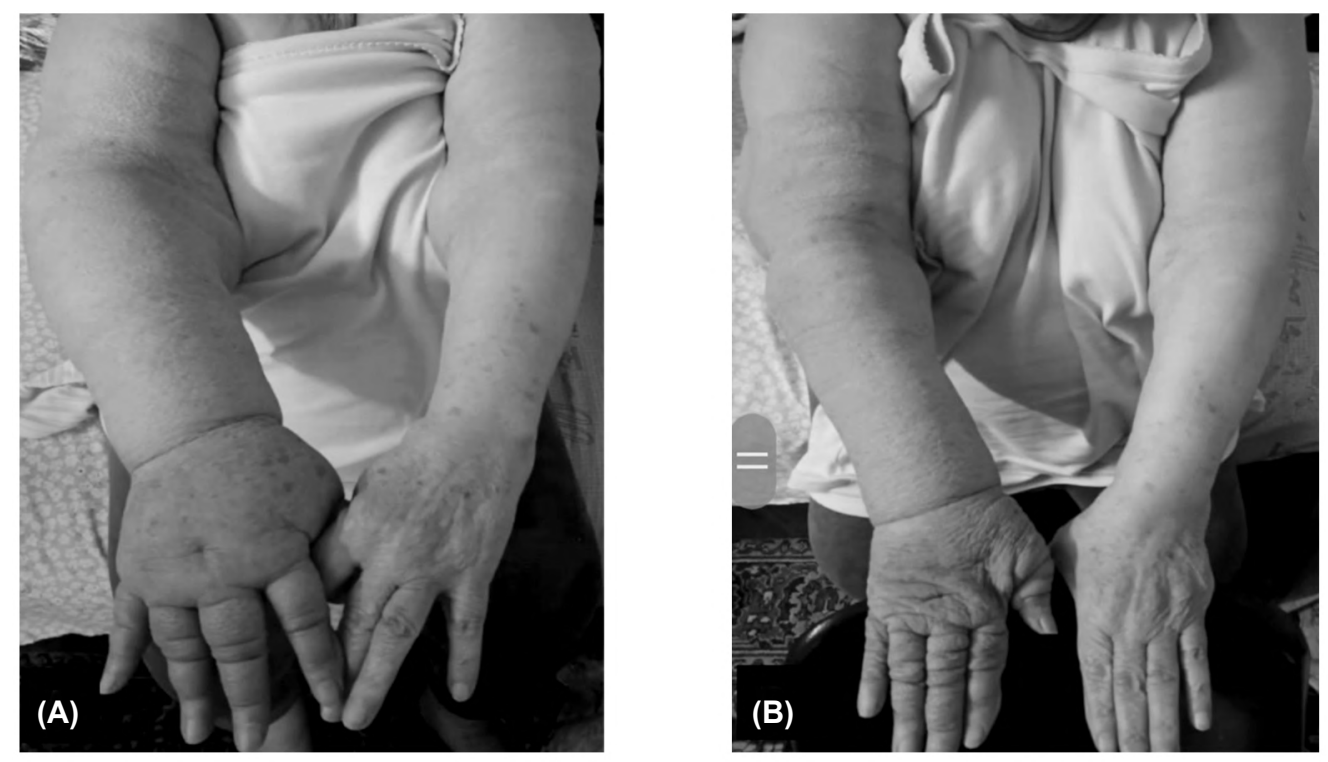

Fig. (3): Endermologie changes in limb volume and circumference. (A): Pre-treatment \& (B): Post-treatment.
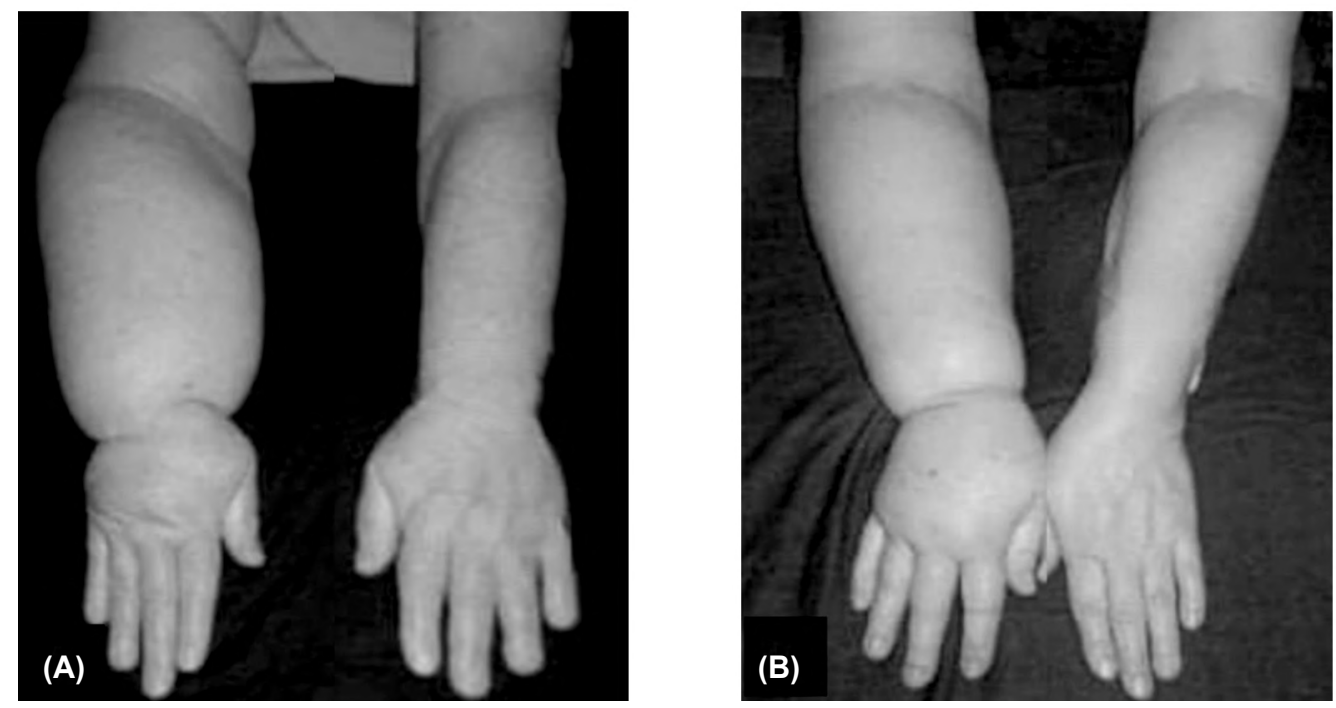

Fig. (4): LLLT changes in limb volume \& circumference. (A): Pre-treatment \& (B): Post-treatment. 


\section{Discussion}

The results of this study agreed with Mogahed et al. [9] who study low-level laser diode on post modified radical mastectomy lymphedema and found that low-level laser diode helps lymphangiogenesis, enhancement of lymphatic drainage, stimulation of macrophage cells and facilitation of the immune system, increasing phagocytic and chemotactic activity of human leukocytes in vitro and decreasing infection risk which is considered one of its advantages.

The results of this study agreed with those of Özçete et al. [10] who demonstrated the effectiveness of kinesio taping and low-level laser therapy in breast cancer-related lymphedema in an arm with arteriovenous fistula for hemodialysis and found that LLLT stimulate lymphatic movement and lymphangiogenesis, soften fibrotic tissues and improve the contractility of the lymphatic vessels that assist the lymph transport. These mechanisms enhance the movement of the fluid accumulated in the extracellular area to the lymphatic system.

The results of this study agreed with the systematic review of low level laser therapy (PBM) for breast cancer-related lymphedema of Baxter et al. [11] who found that eleven clinical trials were identified, of which seven randomized controlled trials (RCTs) were chosen foranalysis. Results indicated that there is strong evidence (three high quality trials) showing LLLT (PBM) was more effective than same treatment for limb circumference/volume reduction at a short-term follow-up. There is moderate evidence (one high quality trial) indicating that LLLT (PBM) was more effective than same laser for short-term pain relief and limited evidence (one low quality trial) that LLLT (PBM) was more effective than no treatment for decreasing limb swelling at short-term follow-up. So concluded LLLT (PBM) may be considered an effective treatment approach for women with BCRL.

The results of this study agreed with the systematic review of effect of LLLT on pain and swellingin women with breast cancer-related lymphedema of Smoot et al. [12] who foundmoderate-strength evidence supports LLLT in themanagement of BCRL, with clinically relevant withingroup reductions in volume and pain immediately after conclusion of LLLT treatments. Greater reductions in volume were found with the use of LLLT than in treatments without it. Implications for cancer survivors LLLT confers clinically meaning ful reductions in arm volume and pain in women with BCRL.
On contrast to this study, Kilmartin et al. [13] who evaluated the effectiveness of LLLT as acomplementary treatment to complete decongestive therapy (CDT) treating lymphedema among breast cancer patients for 12 months post-intervention. Study concluded that there were significant benefits of complementary LLLT for relieving symptoms and improvement of emotional distress in breast cancer patients with lymphedema, while there was no significant reduction in limb volume.

The results of this study were supported also by Mohamed et al. [5] who studied the effectiveness of Endermologie therapy on reducing arm swelling in women post mastectomy. Forty women were assigned for the study with a limb circumference difference of at least $2 \mathrm{~cm}$ compared to the contra lateral limb, the study group received Endermologie therapy and a compression bandaging (each session was 20 minutes at the posterior thorax, upper arm, forearm and the hand twice weekly for 4 weeks) and a control group received a compression bandaging for 4 weeks. The results showed significant reduction in arm swelling in the study as compared to the control group ( $p$-value $<0.05$ ) however both groups showed significant improvement ( $p$-value $<0.001$ ) so concluded that Endermologie therapy can be introduced as a safe modality for post mastectomy lymphedema.

The results of this study agreed with Malloizel et al. [7] who investigated the validity of an IDT protocol combining Endermologie with standard of care in breast cancer related lymphedema. $\mathrm{Pa}$ tients were randomised into three arms as follows: Arm 1: IDT for 5 days with bandages + manual lymphatic drainage. Arm 2: IDT with bandages + manual lymphatic drainage + Cellu M6 for 5 days. Arm 3: Bandages + Cellu M6 for 5 days. During the study, patients will be followed-up for a period of 6 months. The results found that the use of LPG's Cellu M6 in combination with IDT may improve upper limb volume reduction compared with standard of care.

The results of this study came in line with Ahmed, [14] who studied the effectiveness of endermologie on reducing arm edema and shoulder function in women post mastectomy. Twenty women were divided into two groups equal in number, the study group received endermologie therapy 4 days per week for 4 weeks and a decongestive physical therapy (DPT) group. Limb volume, pain and shoulder range of motion (flexion, and abduction) were measured before and after 4 weeks of treatment. The results showed significant reduction in limb volume, and pain in the Endermologie 
group as compared to the DPT group ( $p$-value $<0.001$ ) and increased shoulder ROM (flexion and abduction) in endermologie group as compared to the DPT group ( $p$-value <0.001).

Also, the results of this study agreed with those of Moortgate et al. [15] who investigated the physical and physiological effects of vacum massage on the different skin layers, dermal and epidermal skin structures. Nineteen articles were included in the qualitative synthesis. The two most reported physical effects of vacuum massage were improvement of the tissue hardness and the elasticity of the skin. Besides physical effects, a variety of physiological effects are reported in literature, for example, an increased number of fibroblasts and collagen fibres accompanied by an alteration of fibroblast phenotype and collagen orientation. Little information was found on the decrease of pain and itch due to vacuum massage.

On contrast to this study, Nassab, [16] who examined the evidence behind noninvasive body contouring devices and concluded that the mechanical energy-based devices (Endermologie) have shown only little improvements in terms of circumferential reductions and they require numerous repeated treatments.

\section{Conclusion:}

Based on the scope and findings of this study, it could be concluded that: Endermologie was more effective than LLLT in reducing limb circumference and volume in post mastectomy lymphedema.

\section{References}

1- NEWMAN and TIM (2017): "What is a mastectomy?". Medical News Today; MediLexicon, Intl., 23 May. Web. 2 Jan. 2018.

2- DUDHAGARA R.K. and JAGAD K.: "Physiotherapy management for breast cancer related lymphedema (BCRL): An evidence based study". International Journal of Health Sciences and Research, 10 (2): 162-165, 2020.

3- YANG J.C.S., WU S.C., CHIANG M.H., LIN W.C. and HSIEH C.H.: "Intraoperative identification and definition of functional lymphatic collecting vessels for supermicrosurgical lymphatico-venous anastomosis in treating lymphedema patients". Journal of Surgical Oncology, 117 (5): 994-1000, 2018.

4- SEO D., LEE S. and CHOI W.: "Comparison of real-time ultrasound imaging for manual lymphatic drainage on breast cancer-related lymphedema in individuals with breast cancer: A preliminary study". Physical Therapy Rehabilitation Science, 9 (1): 43-48, 2020.
5- MOHAMED F.A. and ABOL-ATTA H.E.D.M.: "Effectiveness of endermologie technique in post-mastectomy lymphedema". The Medical Journal of Cairo University, 79 (2), 2011.

6- TURGAY T. and DENKÇEKEN T.: "The effect of lowlevel laser therapy on quality of life in post-mastectomy lymphedema patients". Biomedical Research and Therapy, 7 (9): 3971-3976, 2020.

7- MALLOIZEL-DELAUNAY J., CHANTALAT E., BONGARD V., CHAPUT B., GARMY-SUSINI B., YANNOUTSOS A. and VAYSSE C.: "Endermology treatment for breast cancer related lymphedema (ELOCS): Protocol for a phase II randomized controlled trial". European Journal of Obstetrics \& Gynecology and Reproductive Biology, 241: 35-41, 2019.

8- NOSSAIR A., SHAHATA S., WAHBA E. and MAHMOUD M.: "Low level laser versus pneumatic compression pump on lymphedema post mastectomy". Current Science International, 7 (4): 481-485, 2018.

9- MOGAHED H.G.H., BADAWY M.M. and AZIZ N.M.A.: "Low-level laser diode on post modified radical mastectomy lymphedema: A randomized controlled trial". Journal of Advanced Pharmacy Education \& Research, Oct-Dec, 10 (4), 2020.

10- ÖZÇETE Z.A. and EYIGÖR S.: "Kinesio taping and lowlevel laser therapy in breast cancer-related lymphedema in an arm with arteriovenous fistula for hemodialysis". Turkish Journal of Physical Medicine and Rehabilitation, 66 (2): 214, 2020.

11-BAXTER G.D., LIU L., PETRICH S., GISSELMAN A.S., CHAPPLE C., ANDERS J.J. and TUMILTY S.: "Low level laser therapy (photobiomodulation therapy) for breast cancer-related lymphedema: A systematic review". BMC Cancer, 17 (1): 833, 2017.

12- SMOOT B., CHIAVOLA-LARSON L., LEE J., MANIBUSAN H. and ALLEN D.D.: "Effect of low-level laser therapy on pain and swelling in women with breast cancerrelated lymphedema: A systematic review and metaanalysis". Journal of Cancer Survivorship, 9 (2): 287 304, 2015.

13- KILMARTIN L., DENHAM T., FU M.R., YU G., KUO T.T., AXELROD D. and GUTH A.A.: "Complementary low-level laser therapy for breast cancer-related lymphedema: A pilot, double-blind, randomized, placebocontrolled study". Lasers in Medical Science, 35 (1): 95 105,2020

14- AHMED E.T.: "Endermologie technique versus decongestive lymphatic therapy on post-mastectomy related lymphedema". J. Nov. Physiotherapy, 3 (155): 2, 2013.

15- MOORTGAT P., ANTHONISSEN M., MEIRTE J., VAN DAELE U. and MAERTENS K.: "The physical and physiological effects of vacuum massage on the different skin layers: A current status of the literature". Burns \& Trauma, 4 (1): 34, 2016.

16- NASSAB R.: "The evidence behind noninvasive body contouring devices". Aesthetic Surgery Journal, 35 (3): 279-293, 2015. 


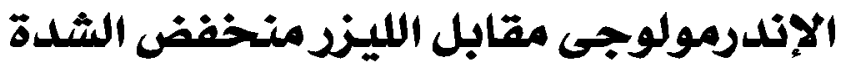

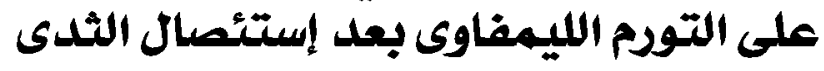

الهدف من الدراسة: أجريت هذه الدراسة للمقارنة بين فعالية الإندرمولوجى مقابل الليزر منخفض الثدة على التوم الليمفاوى بعد إستئصال الثىى.

شارك فى هذه الدراسة ــ سيدة تعانى من توم لميفاوى ثانوى بعد إستئصال الثىى، وتم تقسيمهم عشوائياً إلى مجموعتين متساويتين في العدد: - المجموعة (أ) • ب دقيقة من الإندرمولوجى r مرات في الأسبوع بالإضاقة إلى برنامج العلاج الطبيعى (التصريف الليمفاوى اليدوى، الرياط

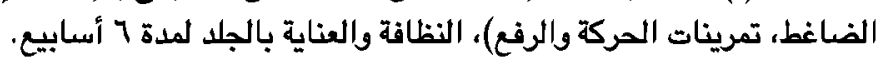
- المجموعة (ب) • ب دقيقة من العلاج بالليز منخفض الثدة ب مرات فى الأسبوع بالإضافة إلى برنامج العلاج الطبيعى (التصريف الليمفاوى

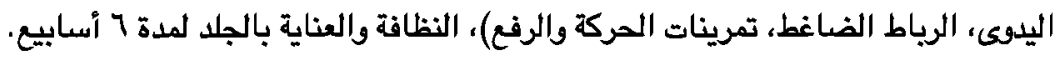

$$
\text { تم تقييم التقدم الليمفاوى في الأطراف العلوية عن طريق محيط وحجم الطرف العلوى قبل وبعد العلاج. }
$$$$
\text { وقد أظهرت النتائج ما يلى : }
$$

أن هناك إنخفاض ذو دلالة إحصائية فى المجموعتين في متوسط قيمة القياسات المحيطية، والقياسات الحجمية ولكن فى المجموعة الأولى المي

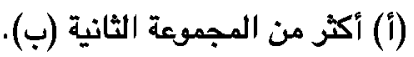

وبعد مناقشة هذه النتائج وتحليلها، تبين أن الإندرملوجى له تأثير أفضل وذو دلالة إحصائية عن الليز منخفض الثَدة في تقليل محيط

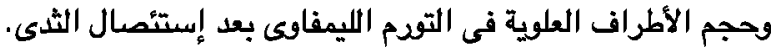

